Prepared for the U.S. Department of Energy under Contract DE-AC05-76RL01830

\title{
Project Overview: Cumulus Humilis Aerosol Processing Study (CHAPS): Proposed Summer 2007 ASP Field Campaign
}

CM Berkowitz

LK Berg

CA Hostetler

JA Ogren

R Ferrare

May 2006

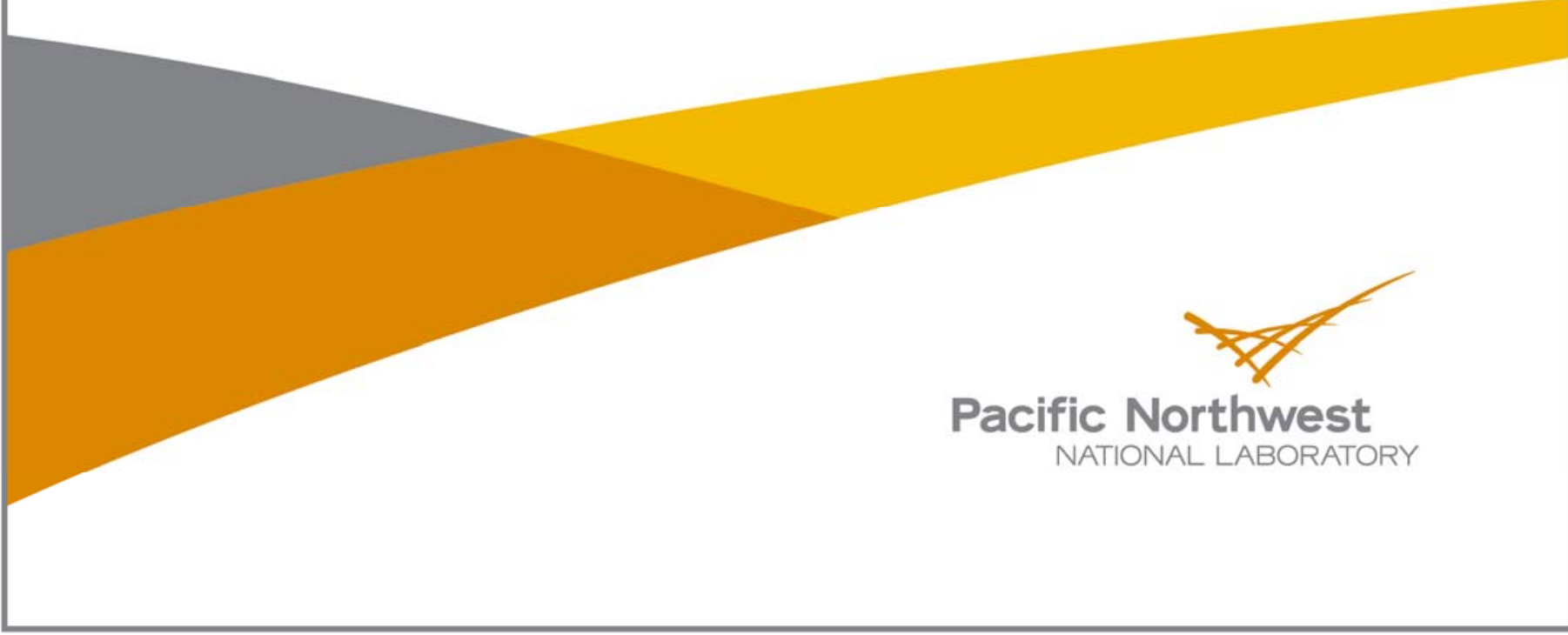




\title{
DISCLAIMER
}

This report was prepared as an account of work sponsored by an agency of the United States Government. Neither the United States Government nor any agency thereof, nor Battelle Memorial Institute, nor any of their employees, makes any warranty, express or implied, or assumes any legal liability or responsibility for the accuracy, completeness, or usefulness of any information, apparatus, product, or process disclosed, or represents that its use would not infringe privately owned rights. Reference herein to any specific commercial product, process, or service by trade name, trademark, manufacturer, or otherwise does not necessarily constitute or imply its endorsement, recommendation, or favoring by the United States Government or any agency thereof, or Battelle Memorial Institute. The views and opinions of authors expressed herein do not necessarily state or reflect those of the United States Government or any agency thereof.

\author{
PACIFIC NORTHWEST NATIONAL LABORATORY \\ operated by \\ BATTELLE \\ for the \\ UNITED STATES DEPARTMENT OF ENERGY \\ under Contract DE-AC05-76RL01830
}

Printed in the United States of America
Available to DOE and DOE contractors from the Office of Scientific and Technical Information,
P.O. Box 62, Oak Ridge, TN 37831-0062;
ph: (865) 576-8401
fax: $(865)$ 576-5728
email: reports@adonis.osti.gov

\begin{abstract}
Available to the public from the National Technical Information Service, U.S. Department of Commerce, 5285 Port Royal Rd., Springfield, VA 22161 ph: (800) 553-6847 fax: $(703) 605-6900$ email: orders@ntis.fedworld.gov online ordering: http://www.ntis.gov/ordering.htm
\end{abstract}

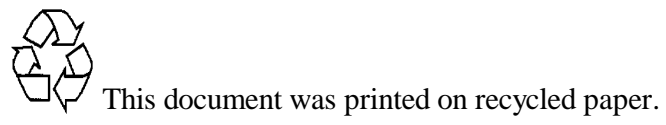


DOE Atmospheric Science Program

\title{
Project Overview: The Cumulus Humilis Aerosol Processing Study (CHAPS)
}

\section{Proposed Summer 2007 ASP Field Campaign}

Date of this Version: May 18, 2006

Carl Berkowitz, Larry Berg

( carl.berkowitz@pnl.gov; larry.berg@pnl.gov )

Atmospheric Chemistry and Meteorology Group

Pacific Northwest National Laboratory

\author{
John Ogren \\ (john.a.ogren@noaa.gov ) \\ Earth System Research Laboratory \\ National Oceanic and Atmospheric Administration
}

Chris A. Hostetler and Rich Ferrare

( chris.a.hostetler@nasa.gov , richard.a.ferrare@nasa.gov )

Science Directorate

NASA Langley Research Center

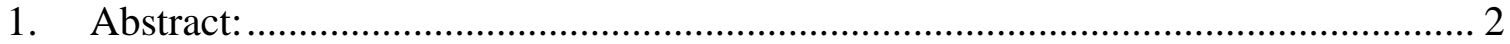

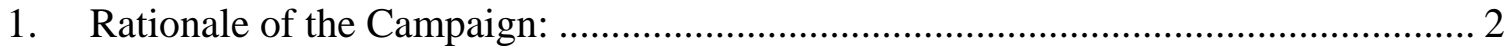

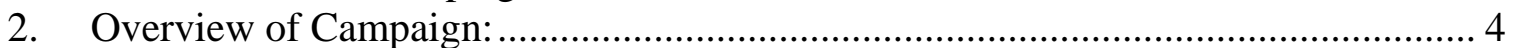

3. The Importance of Aerosol Transformation and Transport by Clouds....................... 5

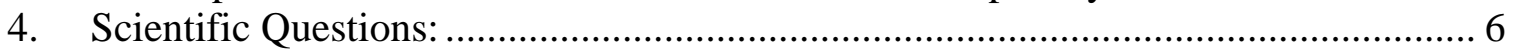

5. Approach: Basic Flight Plans and Sampling Strategy ............................................ 10

6. Why Oklahoma City? Science, logistics and collaboration...................................... 12

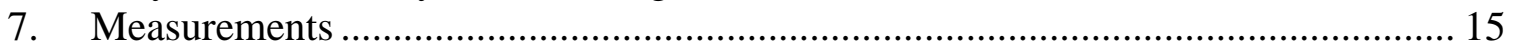

7.1. Proposed Measurements from the G-1 aircraft:............................................... 15

7.2. Proposed measurements from the NASA King Air; ......................................... 17

7.3. Proposed measurements from the surface sites: ............................................... 18

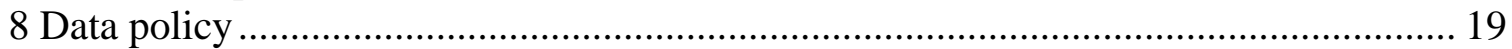

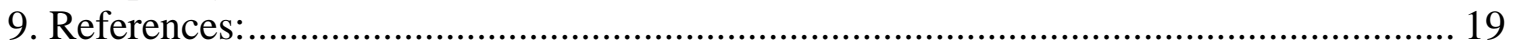




\section{Abstract:}

The primary goal of this campaign is to characterize and contrast freshly emitted aerosols above, within and below fields of cumulus humilis (or fair-weather cumulus, FWC) and to use these observations to address how below-cloud and above-cloud aerosol optical and cloud nucleating properties differ downwind of a mid-size city relative to similar aerosols in air less affected by emissions. The observations from this campaign will also be used to aid in the development and evaluation of parameterizations of the transformation and transport of these aerosols by FWC for use in regional-scale and Global Climate Models. This final product has the potential to reduce the uncertainties associated with the treatment of aerosols by these models. Supporting the in situ observations to be made by the DOE Gulfstream-1 (G-1) aircraft will be profiles of aerosol backscatter and extinction in the vicinity of these clouds to be made with a High Spectral Resolution Lidar (HSRL) onboard the NASA Langley Research Center's King Air Be-200. Measurements will also be made of the composition of aerosols inside and outside of the urban plume in order to characterize both activated and interstitial aerosols. Due to the transient nature and the small spatial scale of the individual FWC, this study will look at the aerosol properties in aggregate, rather then data from individual transects through a cloud. Surface measurements will be used to continuously characterize aerosol and chemical features within the boundary layer. Preliminary discussions with the Cloud and Land Surface Interaction Campaign (CLASIC) science team of the DOE ARM Program have identified overlap between the science questions posed for the CLASIC Intensive Operation Period (IOP) and the proposed ASP campaign suggesting collaboration would benefit both teams.

\section{Rationale of the Campaign:}

As a result of their relatively short lifetime, anthropogenic aerosols have a high degree of variability over both space and time (see Kaufman et al., 2002; IPCC,2001; Andreae et al., 1986 and references therein). Whereas greenhouse gases such as $\mathrm{CO}_{2}$ can have a lifetime characterized by years, the residence time for a typical aerosol is characterized by days to weeks. Kleinman et al. (2006) have found that aerosols undergo rapid changes in size, chemical properties and related hygroscopic and optical properties following their release to the atmosphere. For these reasons, a contrast in aerosol properties would be expected to be found between the upwind and downwind regions of an isolated source. Measurements made downwind of an isolated source of aerosols offer an opportunity to study the transformations of aerosols as they first encounter cloud fields as part of their evolution into 'aged' aerosols.

Metropolitan areas with populations of order one-million people are known to be associated with sub-micron hygroscopic particles produced by automotive exhaust, cooking and industry (Husar et al., 1997). Field observations of the composition and the associated hygroscopic and optical properties of aerosols 
produced from a 'typical' North American city are therefore directly relevant to the scientific goals of ASP since it is thought that aerosols may offset $\sim 50 \%$ of the warming attributed to greenhouse gases (see Kiehl and Briegleb, 1993, IPCC, 2001 and references therein). The relative contribution of aerosol cooling/warming relative to the warming associated with greenhouse gases is a central focus of the ASP program.

Recognition of the complexity of the composition of urban aerosols is now making its way into the modeling community, including an increased appreciation of the significance of carbonaceous material and black carbon (Novakov et al., 1997; Allen et al., 2003a, 2003b). Adding to the growing complexity now known to be associated with these aerosols is recognition that black carbon inside a particle can have a large effect on the absorptive properties of these particles producing a much more strongly absorbing particle than if such material is absent (Ackerman et al., 1981, Martins et al. 1998, Haywood et al. 2000 and Jacobson 2001). Laboratory studies by Chylek et al. (1992) show that a soot kernel within water drops of size 0.1 to $1 \mathrm{~mm}$ results in enhanced absorption compared to the situation in which the soot is uniformly distributed throughout the drop volume. Identifying the extent to which black carbon is found in aerosols associated with an urban plume, relative to the extent to which black carbon is found in aerosols associated with 'clean', air will help assess the climatological significance of this enhanced absorption.

Urban aerosols are known to affect clouds. Wintertime stratiform clouds associated with the urban plumes of Denver $(\mathrm{CO})$ and Kansas City $(\mathrm{MO})$ were found to have a larger number of droplets and smaller median volume diameter than clouds that had not been affected by these urban plumes (Alkezweeny et al., 1993). Such observations have important implications on climate and climate change. A reduction in droplet size has also been postulated to result in brighter clouds with an associated cooling effect to the atmosphere (Nakajima, et al. 2001). As a result of observations such as these, understanding mesoscale downwind effects is requisite to understanding their regional and global effects (Twomey et al., 1984; Charlson et al., 1992). Another link between urban aerosols and cloud has been suggested by Rosenfeld (1999) who noted that smaller cloud droplets have smaller coalescence efficiencies, resulting in reduced precipitation and longer cloud lifetimes, providing yet another link to urban aerosols and climate.

Previous studies have noted that aerosol optical properties are not homogenous in the presence of clouds. Satellite observations have shown increases in aerosol optical depth (AOD) near clouds (Wetzel and Stowe, 1999; Nakajima et al., 2001) although these results may simply be an effect of cloud contamination in seemingly cloud-free pixels. This uncertainty in the behavior of aerosol extinction near clouds and the uncertainty in cloud cover fraction leads to increased uncertainties in determining direct radiative forcing (Coakley et al., 2005). In developing an estimate of the direct effects of anthropogenic aerosols on solar 
radiation, Chung et al. (2005), through the use of satellite observations, groundbased observations and models of aerosol chemistry, transport and radiative transfer, noted that the major contributor to the uncertainty in evaluating atmospheric absorption comes from the uncertainty in the vertical distribution of aerosols and the single scattering albedo of aerosols.

Airborne measurements have also observed small scale variability in AOD. During the Chesapeake Lighthouse and Aircraft Measurements for Satellites (CLAMS) experiment, airborne sun photometer measurements indicated that AOD typically varied by $25-30 \%$ over distances of $50 \mathrm{~km}$ (Redemann et al., 2005). The lack of spectral variability of AOD indicated little variability in the aerosol size distribution, so it was concluded that over the east coast of the U.S. during the summer, AOD variability is caused primarily by the transport and diffusion of similar aerosol types rather than the mixing of aerosol types of different size and composition. It is not clear whether these same results apply to the central U.S. or whether they are unique to the east coast.

\section{Overview of Campaign:}

The primary goal of this field campaign is to characterize freshly emitted aerosols above, within and below fields of cumulus humilis (fair-weather cumulus, FWC) in the vicinity of a mid-size, mid-latitude city. Observations will be made through an measurement program with in situ instrumentation onboard the DOE Gulfstream-1 (G-1) and profiles of aerosol backscatter and extinction measured using the NASA High Spectral Resolution Lidar (HSRL) flown on the NASA Langley King Air Be-200. The King Air will fly above the cloud fields sampled by the G-1. Measurements will be made inside and outside of the urban plume, with the in-cloud observations using a counterflow virtual impactor system to allow separate sampling of a selected set of parameters for activated and interstitial aerosols. Surface measurements will be used to continuously characterize aerosol and chemical features of the boundary layer.

Aircraft sampling will be conducted within fields of FWC in the vicinity of Oklahoma City. Area emissions of organic aerosols around Oklahoma City are on the order of 2 tons day ${ }^{-1} \mathrm{~km}^{-2}$, and area emissions of $\mathrm{SO}_{2}$ are on the order of $8 \times 10^{-4}$ tons day ${ }^{-1} \mathrm{~km}^{-2}$ (based on the NEI-99 version 3 emissions inventory for emissions between 8 am and 9 am CST). By sampling close to the source of this isolated urban plume, we will observe aerosols that will have had few interactions with clouds since their release or formation. Oklahoma City was selected as the site for this campaign for several reasons, foremost of which is its relatively isolated nature, which will make its plume more distinguishable from regionalscale features. Also, FWC are common in the Southern Great Plains (occurring on $40 \%$ of the days; Warren et al. 1986), and once the clouds form they tend to persist throughout the day in a fairly steady fashion (Berg et al. 2006). Finally, collaboration with the ARM CLASIC campaign, also set in Oklahoma, is anticipated to yield additional benefits to both ASP and ARM investigators (see Section 7, 'Why Oklahoma City? Logistics, science and collaboration.') 
While fields of FWC are quite extensive and can have a long lifetime, individual FWC are transient, with a lifetime on the order of only 15-30 minutes, and relatively small in size, generally less then $1 \mathrm{~km}$ in diameter (e.g. Berg et al. 2006). These two factors, in conjunction with the minimum sampling speed of the G-1, will of necessity result in a statistical characterization of the in-cloud and out-of-cloud properties within the cloud layer. Assuming that the airspeed of the G-1 is approximately $100 \mathrm{~ms}^{-1}$, the aircraft will spend on the order of $10 \mathrm{~s}$ or less within each FWC. Thus, it is expected that only a subset of the instrumentation to be deployed will be able to differentiate between clear and cloudy air. Two sets of fast response instruments (described in Section 7) will be carried on the G-1 to separately sample both interstitial aerosol and aerosols within cloud droplets (cloud droplet nuclei, CDN) as the interstitial aerosols and droplets are separated by a CVI inlet.

\section{The Importance of Aerosol Transformation and Transport by Clouds}

The transformation and transport of aerosols from the boundary layer to the free atmosphere by fields of FWC is expected to affect the radiation budget, and hence be of interest to ASP, for a number of reasons.

1) The transport by clouds of 0.1 to $1 \mu \mathrm{m}$ aerosols from within the boundary layer to the free atmosphere results in moving optically important particles from a region of relatively low wind speeds and high net deposition rates to a region of higher wind speeds and negligible deposition, greatly enhancing the particle lifetime and hence aerosol mass loading in areas downwind of the source region. The importance of just the transformation aspect of this process was shown by Lu et al. (2003) who reported that particles above the tops of marine FWC had a unimodal size distribution (with most particles smaller than 0.1 micron) in contrast to particles below these cloud fields that displayed a bimodal distribution (with peaks at $\sim 45 \mathrm{~nm}$ and $200 \mathrm{~nm}$ ). They also found that the total dry aerosol number was greater above cloud top than within the (marine) boundary layer. The importance of just the transport aspect was demonstrated by Cotton et al. (1995) who used Large Eddy Simulations (LES) to show that $30 \%$ of the boundary-layer air passed through a region of FWC in a one-hour period.

In addition, lifting strongly absorbing aerosols from below clouds into and above the cloud layer will alter the energy budget by effectively reducing the insolation reaching lower levels of the atmosphere (Harshvardhan, 1993; Ghan and Penner, 1992). The presence of moderately absorbing aerosols above a bright cloud surface rather than a darker land surface can also change the top of atmosphere (TOA) forcing from cooling to warming.

2) Aerosol particles activated as cloud condensation nuclei are subject to aqueous phase chemistry in cloud drops which can lead to changes in the 
optical properties of the aerosols. An aqueous phase reaction might add sulfate to the cloud drop with the result that once the cloud drop has evaporated, the scattering efficiency, $\mathrm{E}_{\text {scat, }}$ of the aerosol will have increased and the mass absorption efficiency, $E_{a b s}$, will have decreased because of the additional sulfate. The potential importance of these changes stems from the sensitivity of radiative forcing to these quantities. Depending on the surface reflectance and the backscattering fraction, very small changes in the single scattering albedo, $\omega_{0}=E_{\text {scat }} /\left[E_{\text {scat }}+E_{\text {abs }}\right]$, are believed to be associated with a change in sign $( \pm)$ of the direct forcing (Haywood and Boucher, 2000; Hansen et al., 1997).

3) Scavenging and activation is a function of aerosol composition with the result that some types of aerosols that are more readily scavenged (e.g. sulfate) are also more likely to scatter radiation while others that more resistant to scavenging (e.g. soot) are more likely to absorb radiation. Reductions in aerosol scattering efficiency, increases in aerosol absorption and increases in aerosol number density above clouds relative to those below clouds will have a substantial effect on the back scatter of solar radiation to space. It has also been shown that FWCs play an important role in determining the chemical composition of air above cloud top (Taylor et al., 1997; Edy et al. 1996; Thompson et al., 1994; Vukovich and Ching, 1990; Ching and Alkezweeny, 1986; Greenhut, 1986; Ching et al., 1984) suggesting that FWC will also play an important role in determining the characteristics of particles above cloud top.

4) The relative humidity is much lower in the free troposphere then in the boundary layer so reductions would be expected in the size distribution of aerosols associated with hygroscopic swelling and possible changes in the composition as they move from below cloud base to above cloud top. While this is an apparently obvious fact, it is not obvious that models can adequately simulate such changes.

5) Finally, the mass concentration of aerosol particulate matter is the single most important factor in determining the amount of particulate scattering and absorption under clear sky conditions. Cloud processes will affect both aerosol mass of particles processed by the clouds and the total mass concentrations.

\section{Scientific Questions:}

The CHAPS campaign will address the following scientific questions:

Question 1: How do below-cloud and above-cloud aerosol optical and cloud nucleating properties differ downwind of a typical North American city from those properties in air unperturbed by the urban emissions? What are the differences in the: 
a. radiative properties (e.g., single scattering albedo, mass scattering efficiencies),

b. the chemical composition,

c. hygroscopic properties (including capability to serve as $\mathrm{CCN}$ ) and

d. size distribution?

One process that might be important is the dissolution of $\mathrm{SO}_{2}$ into aqueous solution. This process is a strong function of the concentration of $\mathrm{H}_{2} \mathrm{O}_{2}$ and the $\mathrm{pH}$, necessitating the measurement of both $\mathrm{SO}_{2}$ and $\mathrm{H}_{2} \mathrm{O}_{2}$. The addition of $\mathrm{SO}_{2}$ to the drops is likely to increase the aerosol mass when the droplets evaporate upon exiting the cloud (through the oxidation and the production $\mathrm{SO}_{4}{ }^{2-}$ ). The additional aerosol mass will likely change the optical properties of the aerosols, as well as change their hygroscopic properties.

Addressing these questions requires identifying air containing aerosols that have passed through FWC. Aerosols found above cloud top need not have passed through clouds immediately below; they may have arrived at cloud top through advection or subsidence from higher in the atmosphere. These air parcels will be identified through the use of conserved thermodynamic tracers that do not change their value during adiabatic lifting and that mix in a nearly linear manner. These tracers have been employed by many investigators to identify air parcels that have passed through clouds (e.g., Paluch, 1979; Hanson 1984) and it is proposed that such tracers be used to identify air that has been lifted through the FWC. Because the focus of this campaign is on warm non-precipitating clouds, a number of variables can be used that are conserved for both dry and moist adiabatic processes, including total water mixing ratio (defined as the sum of the water vapor, liquid water, and ice in a parcel; $\left(q_{t}\right)$, equivalent potential temperature and liquid-water potential temperature $\left(\theta_{l}\right)^{1}$.

Plots of two conserved variables are known as a conserved variable diagram and can be used to identify air that has passed through clouds. An example of such a diagram, using $\theta_{l}$ and $q_{t}$ is given in Figure 1. These distributions were computed from a LES of the BOMEX field campaign; Figure 1A shows the frequency distribution function (FDF) of all points $1 \mathrm{~km}$ above the surface, while $1 \mathrm{~B}$ shows the $\theta_{l}$ and $q_{t}$ of the cloudy updrafts. Points of the FDF that lie between the updraft points in $1 \mathrm{~B}$ and the layer mean indicate mixtures that have some air that has passed through clouds. Although total water mixing ratio can be difficult to measure within clouds, accurate measurements are needed only below and outside the clouds to determine if air has been processed by FWC.

In addition to thermodynamic variables, measurements of the mixing ratios of insoluble trace gases having only a surface source can be used to indicate air parcels that have recently passed through a cloud field. A number of investigators (Lu et al., 2003; Perry and Hobbs, 1996; Radke and Hobbs, 1991)

${ }^{1}$ Defined at http://amsglossary.allenpress.com/glossary/browse?s=1\&p=26 
have also used regions of high relative humidity around clouds to identify parcels that have been processed by clouds
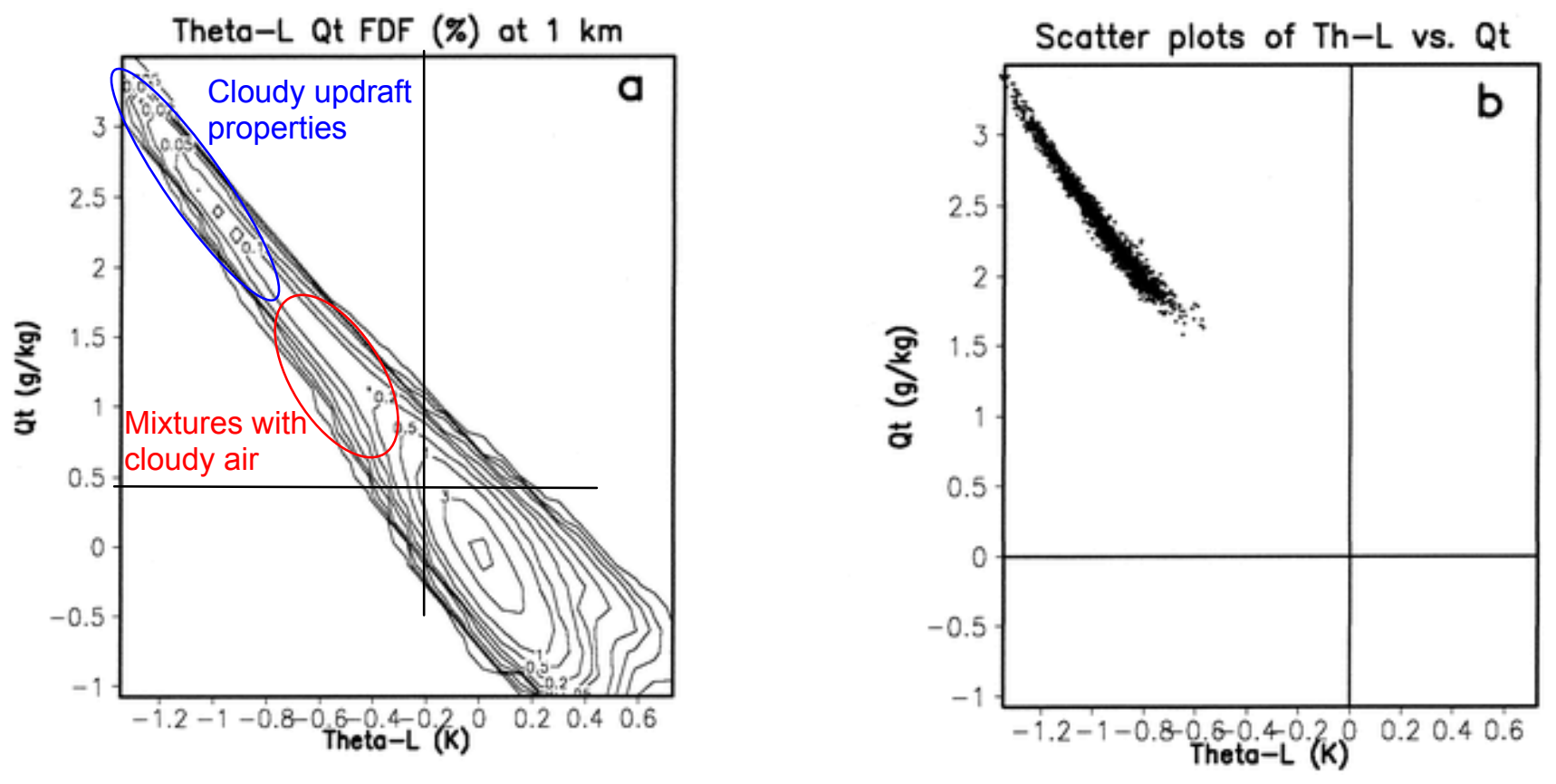

Figure 1. Frequency distribution function of $\theta_{1}$ and $q_{t}$ with the range of cloudy updrafts highlighted with the blue oval and likely mixtures of cloudy and clear air marked with the red oval (A), and scatter plots of $\theta_{l}$ and $q_{t}$ for convective updrafts for a LES of BOMEX (B) (after Wang and Stevens 2000).

Question 2: How does the distribution of aerosol extinction vary in relation to proximity to individual clouds and fields of clouds and why?

Aerosol extinction and optical depth are highly variable in the vicinity of clouds at least in part because of variable $\mathrm{RH}$ and also because of intrinsic changes in aerosol properties due to interactions with clouds. This variability can be important within the context of evaluating the radiative forcing associated with these aerosols and in evaluating the aerosol properties via remote sensing (Coakley et al., 2005). CHAPS will use a High Spectral Resolution Lidar (HSRL) carried by the NASA Langley Research Center's King Air Be-200 to measure profiles of aerosol optical thickness and aerosol intensive parameters (backscatter color ratio, extinction/backscatter ratio, and depolarization). These measurements can be used to investigate the spatial variability of aerosol optical properties over the southern Great Plains within the geographical domain to be sampled via in situ measurements from the G-1. Furthermore, the aerosol extensive (extinction, backscatter) and intensive parameters derived from the HSRL measurements can be used in conjunction with profiles of $\mathrm{RH}$ from radiosondes or the G-1 to infer whether AOD variability is due to changes in aerosol type (e.g. composition, size), aerosol amount or levels of atmospheric moisture. 
Question 3: What are the differences between activated aerosols within the urban plume, and those outside the urban plume? What are the differences between aerosols that have not been activated within and outside the urban plume?

Observations to address this question will follow from the basic flight plan illustrated in Figure 2. Flight plans for the Be-200 and G-1 will consist of transects at right angles to the dominant winds that define the direction of the urban plume. The lengths of these cross-wind transects will be several times the length scale of Oklahoma City thus assuring that the transect ends are outside the plume. Instruments carried by the G-1 will be used to determine which part of the transect is within and outside the plume, e.g., carbon monoxide, thus allowing the associated measurements to be partitioned according to whether they were made within or outside the plume.

Question 4. To what extent can large-scale models with state of the art cloud parameterizations capture the statistical features of the below-above cloud aerosol fields?

One of the ASP program's deliverables is the addition of parameterized aerosol physics and chemistry to an existing cumulus parameterization suitable for inclusion in regional-scale models or GCMs. Because current global and regional-scale models poorly simulate the effects of FWC on aerosols PNNL is developing a module to better treat this aspect of the transformation and transport of aerosols. This code builds on the Cumulus Potential Scheme of Berg and Stull $(2004 ; 2005)$ consisting of one module representing boundary-layer physics and another module representing the macrophysical properties of the clouds (such as mixing between the cloud and environment, total cloud water, cloud-base height and cloud-top). New approaches in climate modeling like the Multi-Scale Modeling Framework, in which two-dimensional cloud-resolving models are each run inside GCM grid box (Randall et al. 2003) still do not explicitly resolve FWC. In most other applications the vertical transport associated with the clouds is represented using parameterizations that were designed for deep convection. Even models which do include a parameterization for FWC, like the NCAR Community Atmosphere Model (CAM3), ignore the subgrid variability of temperature and moisture in the model grid cell with the result that little can be said about the evolution of aerosol properties within these simulated domains (Hack 1994). The observations of this campaign are tailored to evaluating this modeling product

The vertical distribution of aerosols remains one of the largest source of disagreement among models, as shown in several global model intercomparison activities including the Comparison of Large Scale Sulphate Aerosol Models (COSAM; Barrie et al., 2001; Lohmann et al., 2001), Intergovernmental Panel on Climate Change (IPCC, 2001) and the Global Aerosol Model Intercomparison (AEROCOM) in 2004 (Textor et al., 2005; Kinne et al., 2005. Some of the large 
variations between the models noted by Textor included differences in aerosol composition, aerosol lifetime and water content due to hygroscopic growth in ambient air. Although models have shown reasonably good agreement among themselves and with measurements in terms of aerosol optical thickness (AOT), the AEROCOM model intercomparisons have shown that there are large differences in how the various models partition aerosol mass and optical depth among these various components (Kinne et al., 2005). As a result it was found that the models differed in their description of aerosol vertical distribution and optical depth Observations made at low altitudes by the G-1 in conjunction with the observations from the HSRL Be-200 aircraft will provide a rich data set for future modeling studies of the vertical distribution of aerosols.

ASP scientists at NASA have begun investigating the extent to which the intensive aerosol parameters (backscatter and extinction color ratios, depolarization) derived from lidar measurements can be used to infer the vertical distribution of these features and thereby help evaluate models (Ferrare et al., 2006). As part of the 2007 ASP campaign, it is proposed to extend these investigations by using the vertical profiles of aerosol extinction and aerosol intensive parameters from the HSRL to help evaluate the ability of models to reproduce aerosol extinction and optical thickness profiles as well as to help determine how well models can represent horizontal and vertical variations in aerosol types. Lidar measurements made using the HRSL, accompanied with the in situ measurements of aerosol size distribution and relative humidity would be of interest to the ASP work being led by Drs. Steven Ghan and Jerome Fast. These modeling studies include, among other objectives, assessing how well global- and regional-scale models simulate a variety of cloud/aerosol interactions, and therefore depend on observations of the type proposed for CHAPS.

\section{Approach: Basic Flight Plans and Sampling Strategy}

The proposed campaign will consist of an integrated sampling program involving both the G-1 and Be-200 aircraft. The G-1 will make in situ measurements of aerosol concentrations, composition, size distributions, optical properties, cloud nucleating properties below, within and above clouds downwind of Oklahoma City while the Be-200 will use the HSRL to provide remotely observed profiles of aerosol extinction and backscatter. In addition, there will be a surface station to provide observations of boundary layer aerosols and meteorological conditions.

The in situ aircraft sampling will consist of cross-wind legs made below, within and above fields of FWC with the spatial scale of the sampling intended to provide statistics against which to test the fidelity of parameterizations used in large-scale models describing aerosol transport over typical GCM grid cells $(\Delta \mathrm{x} \sim$ $100 \mathrm{~km})$. By centering the campaign in the near-field downwind region of Oklahoma City the G-1 can be used to make cross-wind transects that intersect the urban plume. Such a strategy, used by ASP investigators on a number of 
past campaigns (e.g., Nashville and Houston) will enable in situ sampling of air that is influenced by both local emissions and air that is relatively clean. A schematic of the general sampling strategy is shown in the figure below.

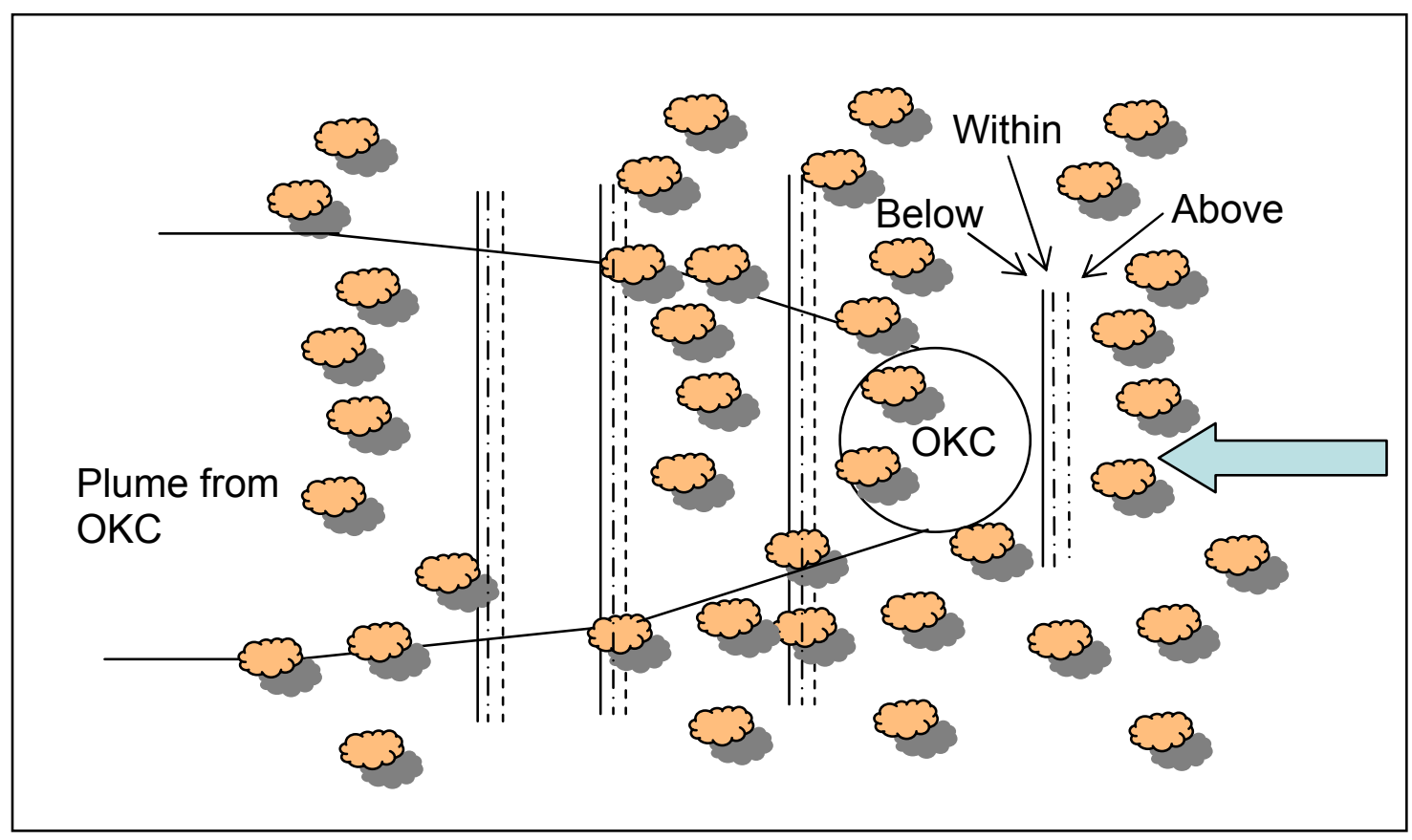

Figure 2: Schematic showing generic flight plan for sampling fields of cumulus within the plume emanating from Oklahoma City. Arrows identify cross-wind transects to be made below, within and above the cloud fields. See text (below).

The wind direction is shown in this figure by the large arrow on the right with fields of FWC extending over the region. Solid vertical lines represent cross-wind transects to be made below cloud base, dashed-dotted lines represent transects made within the clouds and dashed lines represent transects flown above cloud top (these three sets of lines have been displaced slightly for purposes of clarity). Characterization of background fields will be made via short cross-wind transects upwind of Oklahoma City and by measurements made on the tails of the downwind transects. The majority of flight time would be spent making a series of cross-wind transects below-, within and above-cloud directly downwind of Oklahoma City but still relatively close $(<50 \mathrm{~km})$ to its edge. Identification of air that had passed over the city would be made via onboard measurements of compounds associated with urban emissions, e.g., CO. The number of transects will be determined by the availability of G-1 flight hours (both total and per mission), with a balance to be struck between the number of in-cloud transects and the total number of sets of downwind transects.

While the G-1 is making its surveys upwind and downwind of Oklahoma City, the NASA Be-200 will fly directly over the G-1 at an altitude of $25-28 \mathrm{kft}$, acquiring 
lidar profile data to provide vertical context on aerosol and cloud structure above and below G-1. The G-1, in turn will provide in situ measurements of moisture and aerosol microphysics to support the interpretation of the airborne HSRL. The NASA HSRL will also provide guidance for the day to day variations in the G-1 flight plan, directing the G-1 to different altitudes based on real-time lidar profiles of aerosol and cloud vertical distribution. Spirals by the G-1 will be added over ground-sites to be deployed in conjunction with the CLASIC IOP (see Section 5). These spirals will provide profiles of the aerosols and aerosol optical properties, as well as profile of the thermodynamic variables.

It is expected that the study area will, on occasion, have low stratus or stratocumulus, and that sampling within these cloud fields would serve the interests of the ASP program. Aircraft sampling will be made under these conditions as allowed by Federal Aviation Regulations, and agency policies governing the deployment of the DOE and NASA aircraft.

\section{Why Oklahoma City? Science, logistics and collaboration}

\section{Science:}

Oklahoma City is relatively isolated from other urban areas which will simplify distinguishing between 'new' aerosols within the Oklahoma City plume and 'old' aerosols outside the plume, where the plume boundaries will be defined from ancillary observations of carbon monoxide. It is anticipated that close to Oklahoma City new aerosols will dominate over 'old' aerosols and that the measurements will show a contrast between the new and old, the latter dominating outside the urban plume. In addition, the terrain in this region is relatively uniform which minimizes the likelihood that local dynamic forcing by terrain will cause a systematic bias in the formation of clouds.

\section{Logistics}

The aircraft will be within heavily controlled radar air space which is an added safety feature for any airborne campaign.

\section{Collaboration: CLASIC}

Another advantage of a summer 2007 campaign in Oklahoma is the potential for collaboration with the ARM Cloud and Land Surface Interaction Campaign (CLASIC) Intensive Operation Period (IOP). The focus of CLASIC is to advance the understanding of cumulus convection and its controls, particularly those associated with land surface processes. The CLASIC IOP will cover a period of 1-3 months and will straddle the winter wheat harvest when large changes in the land surface lead to large changes in the surface albedo, latent heat flux, and sensible heat flux. A central part of this campaign will be the Center for InterDisciplinary Remotely Piloted Aircraft Studies (CIRPAS) Twin Otter and the NASA ER2. The Twin Otter will make in situ observations of cloud and aerosol microphysics, while the ER2 will make high-altitude over flights with a suite of remote sensing instruments. CLASIC may bring two mobile SMART C-Band radars which will be deployed at various locations within the ARM SGP site. 
Discussions between ASP and CLASIC scientists have identified a number of areas of mutual interest, including:

- Cloud microphysical measurements. The ASP team's interest in microphysics stems from wanting to better understand in-cloud transformations of aerosols. The CLASIC team's interest in microphysics stems from wanting to better understand changes to the cloud properties associated with varying land use and boundary layer properties.

- Aerosol radiative properties. The Twin Otter and G-1 will be equipped with identical instruments for measuring aerosol radiative properties, specifically, aerosol light scattering, hemispheric backscattering, and absorption at three visible wavelengths. Combining the data sets from the two aircraft, along with identical measurements from the ARM Cessna 206 over the SGP Central Facility, will provide a unique evaluation of the spatial variability of aerosol radiative properties.

- Location. The ASP team is proposing a campaign in the area in and around Oklahoma City because this area provides a location to sample within (and outside) of an urban plume coming from a relatively isolated medium size city in the presence of FWC. The CLASIC team has proposed a campaign in Oklahoma as a result of their interest in abrupt change in surface characteristics (e.g., change in land use associated with the harvest of winter wheat) on fluxes and cloud microphysics.

- Season: The ASP team is proposing a campaign during the period of time most closely associated with FWC over central North America. This coincides with the time selected by the CLASIC team based on considerations of winter wheat harvest and associated changes in land surface processes.

There appear to be at least three collaborative efforts that would benefit both the ASP and CLASIC campaigns. First, both programs will benefit by deploying aircraft on the same days. Having both the G-1 and the CIRPAS Twin Otter make early morning observations in the same area to the north of Oklahoma City, followed by having the G-1 continue to make observations in this area throughout the late morning/early afternoon as the Twin Otter extends its observations to the north and south, will provide information on local change to cloud microphysical and aerosol properties (from the combined early morning observations from both aircraft) and regional-scale changes (as the Twin Otter samples to the north and south). There have also been discussions about having the G-1 and Twin Otter fly in a stacked pattern, providing simultaneous observations aerosol properties below and above a field of clouds. This would directly benefit ASP's interest to compare and contrast aerosols in these two domains.

ASP and ARM would like to deploy ground based aerosol instrumentation at the ARM CLASIC super site within the Little Washita Watershed and a ground site with both aerosol and meteorological measurements closer to Oklahoma City. If this can be done then a natural addition to the 'basic aircraft strategy' described 
earlier would be to add profiles over the surface sites or to have concurrent flyovers by the aircraft above the ground sites. Such coordinated efforts would serve the scientific interests of both programs as it would provide additional information on the vertical structure of aerosol concentration, size spectra, optical properties and composition within columns of air extending from the surface to the highest altitude sampled by an aircraft; such observations would serve a number of scientific questions.

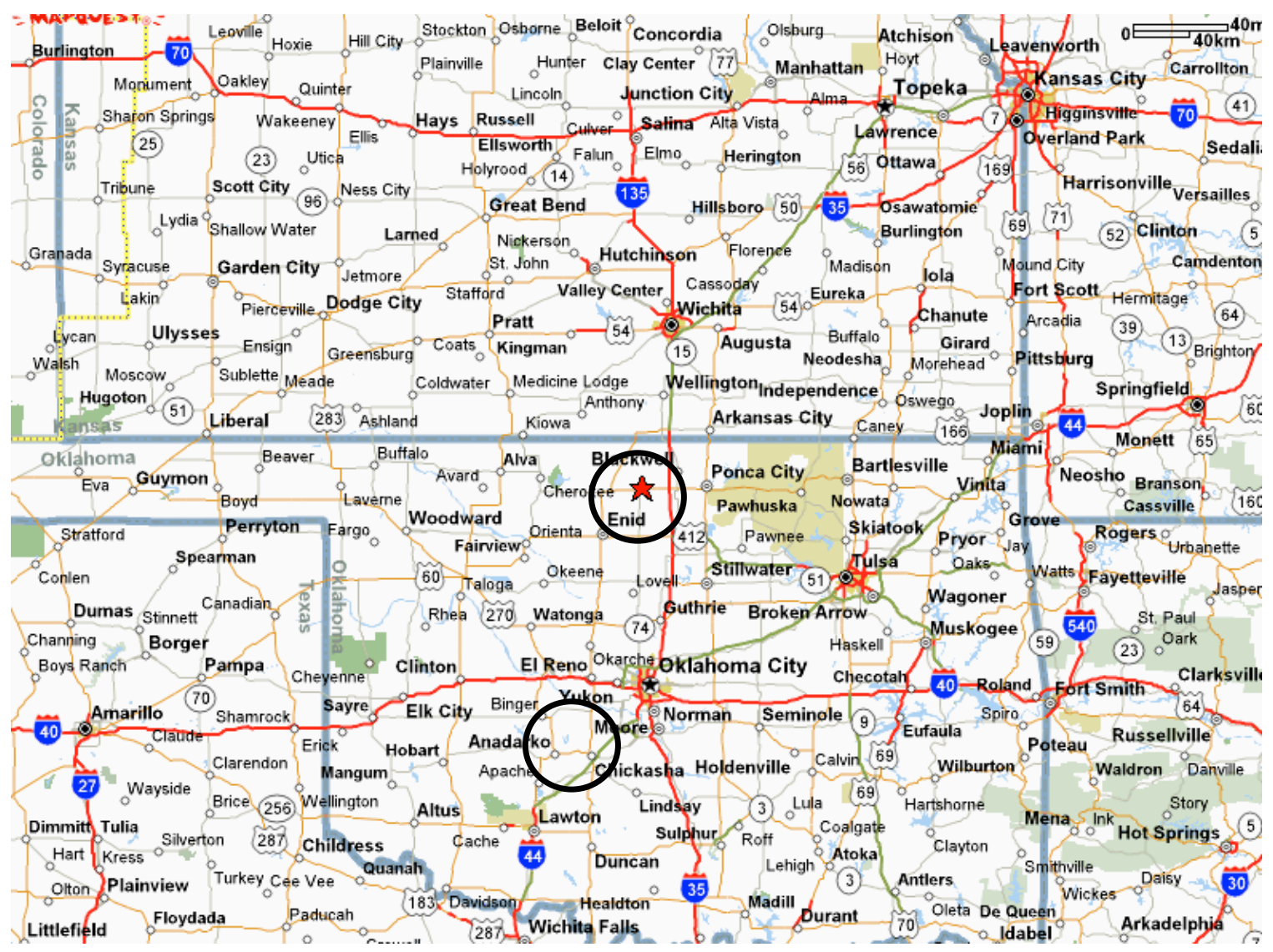

Figure 3: Map illustrating the geographic relation of key areas for the CHAPS campaign and the ARM CLASIC IOP. The CLASIC IOP plan calls for aircraft transects between the Little Washita Watershed (northeast of Lawton, OK) and the SGP/Central Facility, both indicated by the large circles. The ASP plan calls for repeated flights in the vicinity of Oklahoma City.

A third area of common interest is the planetary boundary layer (PBL) depth. The PBL contains the roots of the FWC of interest to the ASP investigators and is the area of active mixing of interest to the CLASIC scientists. ASP scientists from NASA/Langley will provide measurements of PBL height using the aerosol backscatter and extinction profiles measured by the HSRL.

There are differences in the tentative logistical plans for both campaigns (Figure 3). The G-1 flights will be centered near Oklahoma City, with most of the flights being made less than $50 \mathrm{~km}$ downwind of the city (where 'downwind' would be determined by that days' synoptic pattern). In contrast, the Twin Otter 
deployments for the CLASIC IOP will focus on a north-south transect between the SGP Central Facility and the Little Washita Watershed, which is located about $100 \mathrm{~km}$ south of Oklahoma City. There is not perfect overlap in the sampling domains of the two campaigns, but the overlap is significant enough that observations from one aircraft should be able complement those from the other.

\section{Measurements}

\subsection{Proposed Measurements from the G-1 aircraft:}

The priority for instrument deployment, given limitations on space and power on the G-1, is to focus on the optical and chemical properties of aerosols. The core package consists of two identical sets of instruments to measure aerosol scattering and absorption with one set of measurements to be made from a counter-flow virtual impactor $(\mathrm{CVI})$ inlet and another set of measurements to be made from an inlet that allows passage of interstitial aerosols. The CVI system takes advantage of the higher inertia of cloud drops to draw them through a slight counter-flow into the measurement system while smaller particles are unable to overcome the counter-flow. Downstream of the CVI the cloud drops will be evaporated and the resulting cloud droplet nuclei (CDN) fed to aerosol instrumentation to characterize their optical, chemical and physical (size, number and shape) and cloud activation properties.

The interstitial inlet will also feed an airstream to an Aerodyne Aerosol Mass Spectrometer which will let us characterize the composition of these aerosols. The airstream from the interstitial inlet will also be fed into both a fast tandem DMA system and a PILS system. The size distribution of cloud drops will come from a DMT CAPS probe (cloud droplet size between .3 and 50 microns, precipitation droplet sizing between $25-1550$ microns). The G-1 PCASP system will also be employed to measure particles between 0.1 and 3 microns at ambient $\mathrm{RH}$. State parameters (temperature, pressure, moisture) are part of the standard suite of G-1 measurements. A 5-port gust probe built into the G-1 will provide vertical wind speeds and turbulence measurements. Gas phase measurements will consist of $\mathrm{CO}$ (Vacuum UV), $\mathrm{O}_{3}$ (the NOAA B2B system), $\mathrm{SO}_{2}$ and $\mathrm{H}_{2} \mathrm{O}_{2}$. Onboard radiometric measurements will include UV radiation (up- and downwelling), short-wave irradiance (up and down), long-wave irradiance (up and down) and short-wave spectral irradiance (up and down).

The horizontal cross sections of individual FWC are relatively small, on the order of $1 \mathrm{~km}$. Given the G-1 travels at approximately $100 \mathrm{~ms}^{-1}$, this gives a residence time of $10 \mathrm{~s}$ or less within the clouds. Measurements of the aerosols optical properties both inside and outside of the clouds will be possible because of the fast response times of these instruments. Other measurements, such as those of the AMS and PILS will not be able to distinguish between the clear and cloudy air. But the majority of each flight leg will be in clear air, so that it should be possible to measure the chemical properties of the aerosols in the cloud layer. 
Table 1: Duplicate instruments sampling from both the CVI and non-CVI inlet.

\begin{tabular}{|l|c|l|c|}
\hline \multicolumn{1}{|c|}{ Parameter } & $\begin{array}{c}\text { Response } \\
\text { Time (s) }\end{array}$ & \multicolumn{1}{|c|}{ Proposed Method } & $\begin{array}{c}\text { Detection Limit or } \\
\text { Measurement Range }\end{array}$ \\
\hline $\begin{array}{l}\text { Light scattering } \\
\text { coefficient }\end{array}$ & 1 & 3-wavelength nephelometers & $0.1 \mathrm{Mm}^{-1}$ \\
\hline Aerosol absorption & 4 & 3-wavelength PSAP & $0.2 \mathrm{Mm}^{-1}$ \\
\hline $\begin{array}{l}\text { Cloud condensation } \\
\text { nuclei at fixed } \\
\text { supersaturation } \\
\text { per inlet, } 4 \text { total) }\end{array}$ & 1 & $\begin{array}{l}\text { Droplet Measurement Tecnology } \\
\text { (DMT) Cloud Condensation } \\
\text { Nuclei Counter (CCN) }\end{array}$ & $\begin{array}{c}\text { Supersaturation 0.07- } \\
3 \%\end{array}$ \\
\hline $\begin{array}{l}\text { Aerosol size } \\
\text { distribution }\end{array}$ & 1 & $\begin{array}{l}\text { Fast Integrated Mobility } \\
\text { Spectrometer }\end{array}$ & $15-1000 \mathrm{~nm}$ \\
\hline $\begin{array}{l}\text { Aerosol } \\
\text { composition }\end{array}$ & 30 & $\begin{array}{l}\text { Time-Resolved Aerosol Collector } \\
\text { (TRAC) }\end{array}$ & $0.2-7 \mu \mathrm{m}$ \\
\hline Water Vapor & 1 & TDL H20 & $\sim 0-10 \mathrm{~g} / \mathrm{kg}$ \\
\hline Particle Number & 1 & $\begin{array}{l}\text { TSI Condensation Particle } \\
\text { Counter (CNC) } \times 2\end{array}$ & $>3 \mathrm{~nm}$ \\
\hline
\end{tabular}

Table 2: Unique instruments sampling from the non-CVI inlet.

\begin{tabular}{|c|c|c|c|}
\hline Parameter & $\begin{array}{l}\text { Response } \\
\text { Time (s) }\end{array}$ & Proposed Method/contributor & $\begin{array}{l}\text { Detection Limit or } \\
\text { Measurement Range }\end{array}$ \\
\hline Hygroscopicity & 120 & $\begin{array}{l}\text { Hygroscopicity analyzer (H- } \\
\text { FIMS) }\end{array}$ & \\
\hline $\begin{array}{l}\text { Aerosol } \\
\text { composition }\end{array}$ & 30 & $\begin{array}{l}\text { Time-Resolved Aerosol Collector } \\
\text { (TRAC) }\end{array}$ & $0.2-7 \mu \mathrm{m}$ \\
\hline $\begin{array}{l}\text { Submicron aerosol } \\
\text { size }\end{array}$ & 30 & SMPS & $\begin{array}{l}0.1-33 \mu \mathrm{m} ; 20-10^{7} \\
\text { particles/cm }\end{array}$ \\
\hline $\begin{array}{l}\text { Size-resolved EC } \\
\text { mass }\end{array}$ & 1 & $\begin{array}{l}\text { Droplet Measurement } \\
\text { Technology Single Particle Soot } \\
\text { Photometer (SP2)/ }\end{array}$ & $\sim 5000$ particles/s. \\
\hline $\begin{array}{l}\text { Submicron bulk } \\
\mathrm{OC}, \mathrm{SO}_{4}, \mathrm{NO}_{3}, \mathrm{Cl} \\
\left.\mathrm{NH}_{4} \mathrm{~g} \mathrm{~m}^{-3}\right)\end{array}$ & 30 & Aerosol mass spectrometry & variable \\
\hline $\begin{array}{l}\text { Particle ionic } \\
\text { composition }\end{array}$ & 180 & Particle-in-liquid system & $0.1 \mu \mathrm{g} / \mathrm{m}^{3}$ \\
\hline $\begin{array}{l}\text { Carbon Monoxide } \\
\text { (CO) }\end{array}$ & 1 & VacuumUV & $5 p p b v$ \\
\hline $\begin{array}{l}\text { Sulfur Dioxide } \\
\left(\mathrm{SO}_{2}\right)\end{array}$ & 2 & UV Pulsed Fluorescence & 200-300pptv \\
\hline Ozone $\left(\mathrm{O}_{3}\right)$ & 10 & B2B Ozone Analyzer & $0-1000 \mathrm{ppb}$ \\
\hline $\begin{array}{l}\text { Hydrogen Peroxide } \\
\left(\mathrm{H}_{2} \mathrm{O}_{2}\right)\end{array}$ & 60 & 3-Channel Peroxide System & \\
\hline
\end{tabular}


Table 3: Aerosol and cloud droplet sizing instruments mounted on the noise of the G-1

\begin{tabular}{|l|c|l|c|}
\hline \multicolumn{1}{|c|}{ Parameter } & $\begin{array}{c}\text { Response } \\
\text { Time (s) }\end{array}$ & Proposed Method & $\begin{array}{c}\text { Detection Limit or } \\
\text { Measurement Range }\end{array}$ \\
\hline $\begin{array}{l}\text { Aerosol size } \\
\text { distribution }\end{array}$ & 1 & PCASP & $0.17-3 \mu \mathrm{m}$ \\
\hline $\begin{array}{l}\text { Aerosol and Droplet } \\
\text { Size Distribution }\end{array}$ & & $\begin{array}{l}\text { DMT Cloud aerosol and } \\
\text { precipitation spectrometer }\end{array}$ & $\begin{array}{c}0.5-50 \mu \mathrm{m} \& 25-1550 \\
\mu \mathrm{m}\end{array}$ \\
\hline
\end{tabular}

Table 4: Standard meteorological measurements.

\begin{tabular}{|c|c|c|c|}
\hline Parameter & $\begin{array}{c}\text { Response } \\
\text { Time (s) }\end{array}$ & Proposed Method/contributor & $\begin{array}{l}\text { Detection Limit or } \\
\text { Measurement Range }\end{array}$ \\
\hline $\begin{array}{l}\text { Turbulent Wind } \\
\text { Components } \\
(\mathrm{u}-, \mathrm{v}-, \mathrm{w}-)\end{array}$ & 0.1 & Gust Probe & $<0.5 \mathrm{~m} \mathrm{~s}^{-1}$ \\
\hline Water Vapor $\left(\mathrm{H}_{2} \mathrm{O}\right)$ & 0.1 & Lyman Alpha Absorption & $\pm 0.1 \mathrm{~g} \mathrm{~m}^{-3}$ (est.) \\
\hline $\begin{array}{l}\text { Liquid Water } \\
\text { Concentration } \\
\text { (LWC) }\end{array}$ & 1 & $\begin{array}{l}\text { Gerber PVM-100A Probe (optical } \\
\text { light scattering) }\end{array}$ & $\begin{array}{c}0 \text { to } 10 \mathrm{~g} / \mathrm{m} 3,2 \text { to } 70 \\
\text { microns }\end{array}$ \\
\hline Air Temperature & 0.1 & Platinum Resistance & $\pm 0.5^{\circ} \mathrm{C}$ \\
\hline Dewpoint & 1 & Chilled Mirror & Dew: $\pm 0.2^{\circ} \mathrm{C}$ \\
\hline Altitude & 1 & Barometric & $<1 \mathrm{mb}$ \\
\hline Position & 1 & GPS & $<3 \mathrm{~m}$ \\
\hline $\begin{array}{l}\text { *UV radiation, up- } \\
\text { and downwelling }\end{array}$ & 1 & Eppley radiometer & $295-385 \mathrm{~nm}$ \\
\hline $\begin{array}{l}\text { *Short-wave } \\
\text { irradiance, up- and } \\
\text { downwelling }\end{array}$ & 1 & Eppley PSP Pyranometer/PNNL & $285-2800 \mathrm{~nm}$ \\
\hline $\begin{array}{l}\text { *Long-wave } \\
\text { irradiance, up- and } \\
\text { downwelling }\end{array}$ & 1 & Eppley PIR Pyrgeometer/PNNL & $4-50 \mathrm{~nm}$ \\
\hline $\begin{array}{l}{ }^{*} \text { Short-wave } \\
\text { spectral irradiance, } \\
\text { up- and } \\
\text { downwelling }\end{array}$ & 1 & Yankee MFR radiometer/PNNL & $\begin{array}{c}415,500,615,665,862 \\
\text { and } 940 \mathrm{~nm} ; 10 \mathrm{~nm} \\
\text { FWHM }\end{array}$ \\
\hline $\begin{array}{l}{ }^{*} \text { Surface/Sky IR } \\
\text { temperature }\end{array}$ & 1 & PRT 5 IR radiometry/PNNL & $\begin{array}{l}9.5-11.5 \text { micron, }-20 \text { to } \\
50 \mathrm{C}\end{array}$ \\
\hline
\end{tabular}

* These airborne radiation measurements are being considered in the event that 3-dimensaional radiative transfer modeling studies will be part of the analysis, although no such studies are planned at this time.

7.2. Proposed measurements from the NASA King Air;

Measurements to be made from the Langley Research Center King Air Be-200 are shown in Table 4, below: 
Table 5: Measurements to be made from the NASA King Air Be-200.

\begin{tabular}{|l|l|l|}
\hline Parameter & $\begin{array}{l}\text { Horizontal } \\
\text { Resolution }(\mathrm{m})\end{array}$ & $\begin{array}{l}\text { Vertical } \\
\text { Resolution }(\mathrm{m})\end{array}$ \\
\hline $532 \mathrm{~nm}$ backscatter & 50 & 30 \\
\hline $532 \mathrm{~nm}$ aerosol depolarization & 50 & 30 \\
\hline $532 \mathrm{~nm}$ extinction & 1500 & 300 \\
\hline $1064 \mathrm{~nm}$ backscatter & 50 & 30 \\
\hline $1064 \mathrm{~nm}$ aerosol depolarization & 50 & 30 \\
\hline
\end{tabular}

A very useful meteorological measurement to be made by the HSRL is height of the planetary boundary layer The PBL contains the roots of the FWC of interest to the ASP investigators and the mixing of interest to the CLASIC scientists. The aerosol backscatter and extinction profiles measured by the HSRL can be used to measure PBL height. Lidar systems have been widely used to examine the structure and variability of the PBL top and to derive the entrainment zone depth (e.g. Cohn and Angevine, 2000; Brooks, 2003). The long duration ( 3.5 hour, $1200 \mathrm{~km}$ flight leg) of the NASA Langley King Air is well suited for extensive mapping of the PBL using the lidar technique. Also, since this aircraft will be flying at high $(\sim 8.5 \mathrm{~km})$ altitude exclusively, with little or no changes in altitude, the lidar measurements can provide long, uninterrupted measurements of the PBL and entrainment zone, and so will not be interrupted due to changes in altitude required for in situ sampling of aerosols.

\subsection{Proposed measurements from the surface sites:}

The possibility of adding an aerosol measurement station to the CLASIC science team super site in the Little Washita Watershed is under consideration. In addition, the ASP/CHAPS team is looking into establishing a second surface site in the vicinity of Oklahoma City. The purpose of both sites would be to provide continuous aerosol and meteorological observations within the boundary layer in which the roots of the FWC are located.

At a minimum, instruments similar to those put in the field at surface stations deployed during past campaigns (e.g., at Pt. Reyes during the 2005 MASE campaign) would be deployed. These have included aerosol microphysics and optics (nephelometer, PSAP), aerosol size distribution (PCASP), and particle sampling for off-line electron microscope analysis (Table 5). Specific measurements to be made at the surface site(s) will be determined by the available resources for the addition of these surface sites. 
Table 6: Measurements to be made at the surface site(s).

\begin{tabular}{|c|c|c|c|}
\hline Parameter & $\begin{array}{l}\text { Respon } \\
\text { se Time } \\
\text { (s) }\end{array}$ & $\begin{array}{c}\text { Proposed } \\
\text { Method/contributor }\end{array}$ & $\begin{array}{l}\text { Detection Limit or } \\
\text { Measurement Range }\end{array}$ \\
\hline $\begin{array}{l}\text { Light scattering } \\
\text { coefficient }\end{array}$ & 1 & $\begin{array}{l}\text { 3-wavelength } \\
\text { nephelometers }\end{array}$ & $0.1 \mathrm{Mm}^{-1}$ \\
\hline Aerosol absorption & 4 & 3-wavelength PSAP & $0.2 \mathrm{Mm}^{-1}$ \\
\hline $\begin{array}{l}\text { Particle number } \\
\text { concentration }\end{array}$ & 1 & $\begin{array}{l}\text { TSI Model } 3010 \\
\text { Condensation Particle } \\
\text { Counter }\end{array}$ & $\begin{array}{c}10 \mathrm{~nm}-3 \mu \mathrm{m} \text { particles; 0- } \\
50,000 \text { particles } / \mathrm{cm}^{3}\end{array}$ \\
\hline Aerosol size distribution & 1 & PCASP & $(0.17-3 \mu \mathrm{m})$ \\
\hline Aerosol composition & 30 & $\begin{array}{l}\text { Time-Resolved Aerosol } \\
\text { Collector (TRAC) }\end{array}$ & $0.2-7 \mu \mathrm{m}$ \\
\hline $\begin{array}{l}\text { Submicron bulk OC, } \\
\mathrm{SO}_{4}, \mathrm{NO}_{3}, \mathrm{Cl}, \mathrm{NH}_{4}\end{array}$ & 30 & $\begin{array}{l}\text { PNNL: Aerosol mass } \\
\text { spectrometry }\end{array}$ & variable \\
\hline $\begin{array}{l}\text { Profiles of temperature } \\
\text { and water vapor }\end{array}$ & & $\begin{array}{l}\text { Visialia Digi-Cora } \\
\text { radiosonde system }\end{array}$ & \\
\hline $\begin{array}{l}\text { Profiles of wind speed } \\
\text { and direction }\end{array}$ & 1800 & Visialia radar wind profiler & \\
\hline
\end{tabular}

\section{Data policy}

All participants in this campaign will be expected to follow the ASP Data Policy as given in http://www.asp.bnl.gov/datapolicy050505.html ('ASP Data Policy, Draft $2,2005-05-05)$. The goal of this policy, and an important part of CHAPS, is to widen the audience of potential end-users and to foster collaborations among campaign participants and with outside users.

\section{References:}

Ackerman, T.P. and Toon, O.B. Absorption of visible radiation in atmosphere containing mixtures of absorbing and non-absorbing particles. Appl. Opt. 20 3661-3668, 1981.

Alkezweeny, A. J., Burrows, D.A. and Grainger, C.A. Measurements of clouddroplet-size distributions in polluted and unpolluted stratiform clouds. J. App.Met. 32(1), p105-115, 1993.

Allen, J.D. Jimenez, J.L.; Williams, P.I.; Alfarra, M.R.; Bower, K.N.; Jayne, J.T.; Coe, H.; Worsnop, D.R., Quantitative sampling using an Aerodyne aerosol mass spectrometer. 1. Techniques of data interpretation and error analysis, Journal of Geophysical Research, v 108, n D3, p AAC1-1-10, 16 Feb. 2003a.

Andreae, M.O., et al.. External mixture of sea salt, silicates, and excess sulfate in marine aerosols. Science 232, 1620-1623, 1986.

Barrie, L. A., et al., A comparison of large-scale atmospheric sulphate aerosol models (COSAM): Overview and highlights, Tellus, 53B, 615-645, 2001. 
Berg, L. K., and R. B. Stull, 2004: Parameterization of joint frequency distributions of potential temperature and water vapor mixing ratio in the daytime convective boundary layer. J. Atmos. Sci., 61, 813-828.

Berg, L. K., and R. B. Stull, 2005: A simple parameterization coupling the convective daytime boundary layer and fair-weather cumuli. J. Atmos. Sci., 62, 1976-1988.

Berg, L. K., E. Kassianov, C. N. Long, and W. I. Gustafson Jr., 2006: A climatology of fair-weather cloud cover at the ARM SGP Site: Temporal and spatial variability. $16^{\text {th }}$ Annual ARM Science Team Meeting, Albuquerque, NM.

Brooks I. M.. Finding boundary layer top: application of a wavelet covariance transform to lidar backscatter profiles. J. Atmos. Ocean. Tech., 20, 8, 10921105, 2003.

Charlson, R. J. et al. Climate forcing of anthropogenic aerosols. Science 255, 423-430, 1992.

Ching JKS and AJ Alkezweeny. "Tracer study of vertical exchange by cumulus clouds." Journal of Climate and Applied Meteorology 25:1702-1711, 1986.

Ching JKS, EE Uthe, BM Morley, and W Viezee. Observational Study of Transport in the Free Troposphere. 154-157. Portland, OR, USA, American Meteorological Soc, Boston, MA, USA. 1984.

Chung, C. E., V. Ramanathan, D. Kim, and I. A. Podgorny (2005), Global anthropogenic aerosol direct forcing derived from satellite and ground-based observations, J. Geophys. Res., 110, D24207, doi:10.1029/2005JD006356.

Chylek, P., and J. Hallett, Enhanced absorption of solar radiation by cloud droplets containing soot particles in their surface, 'Quarterly Journal of the Royal Meteorological Society, 118(503), Jan 1992, p 167-72.

Coakley, J.A. Jr, Using Remote Sensing to Deduce the Aerosol Direct and Indirect Radiative Forcing of Climate, OSA Hyperspectral Remote Sensing of the Atmosphere, Alexandria, VA, 2005.

Cohn, S. A., and W. M. Angevine, Boundary-layer height and entrainment zone thickness measured by lidars and wind profiling radars. J. Appl. Meteor., 39, 1233-1247, 2000.

Cotton WR and RA Anthes.. Storm and Cloud Dynamics. Academic Press, San Diego, 1989.

Cotton WR, GD Alexander, R Hertenstein, RL Walki, RL McAnelly, and M Nicholls. "Cloud Venting-A review and some new global estimates." Earth Science Reviews 39:169-206. 1995.

Edy J, S Cautenet, and P Bremaud. "Modeling ozone and carbon monoxide redistribution by shallow convection over the Amazonian rain forest." Journal of Geophysical Research-Atmospheres 101(D22):28671-28681. 1996.

Ferrare, R., E. Browell, S. Ismail, G. Chen, Y.J. Kaufman, M. Chin, V. Brackett, C. Butler, M. Clayton, S. Kooi, M. Fenn, A. Notari, P.Russell, J. Redemann, J. Livingston, A. Clarke, J.F. Leon, Characterization of Aerosols using airborne lidar and MODIS, MODIS Science Team Meeting, http://modis.gsfc.nasa.gov/sci team/meetings/200601/atmos.php , Jan. 2006, 
Hack, J. J., 1994: Parameterization of moist convection in the National Center for Atmospheric Research community climate model (CCM2). J. Geophys. Res., 99, 5551-5568.

Ghan SJ and JE Penner. "Smoke, Effect on Climate." Encyclopedia of Earth System Science 4:191-198, 1992

Greenhut GK. "Transport of ozone between boundary layer and cloud layer by cumulus clouds." Journal of Geophysical Research 91(D8):8613-8622, 1986.

Hansen J, M Sato, and R Ruedy. "Radiative forcing and climate response." Journal of Geophysical Research-Atmospheres 102(D6):6831-6864, 1997.

Harshvardhan, "Aerosol-Climate Interactions." Chapter 3 in 'Aerosol-CloudClimate Interactions, P.V. Hobbs (Ed.), International Geophysics Series Vol. 54, Academic Press. 1993.

Haywood $\mathrm{J}$ and $\mathrm{O}$ Boucher. "Estimates of the direct and indirect radiative forcing due to tropospheric aerosols: a review." Reviews of Geophysics 38(4):513543. 2000.

Husar, R.B., Prospero, J. and Stowe, L.L. Characterization of tropospheric aerosols over the oceans with the NOAA AVHRR optical thickness operational product. J. Geophys. Res. 102, 16889-16909, 1997

Intergovernmental Panel on Climate Change, Climate Change 2001: The Scientific Basis 572 pp., J. T. Houghton, Y. Ding, D.J. Griggs, M. Noguer, P. J. van der Linden and D. Xiaosu (Eds.) Cambridge University Press, UK. pp 944, 2001.

Jacobson, M.Z. Strong radiative heating due to the mixing state of black carbon in atmospheric aerosols. Nature 409, 695-697, 2001.

Kaufman, Y. J., Tanre D. and Boucher, OI. A satellite view of aerosols in the climate system, Nature 419, 215-223, 2002.

Kiehl, J.T. and Briegleb, B.P. The relative roles of sulfate aerosols and greenhouse gases in climate forcing. Science 260, 311-314, 1993

Kinne, S., Schulz, M., Textor, C., Guibert, S., Bauer, S., Berntsen, T., Berglen, T., Boucher, O., Chin, M., Dentener, F., Diehl, T., Feichter, H., Fillmore, D., Ghan, S., Ginoux, P., Gong, S., Grini, A., Hendricks, J., Horowitz, L., Isaksen, I., Iversen, T., Koch, D., Krol, M., Lauer, A., Lamarque, J. F., Liu, X., Montanaro, V., Myhre, G., Penner, J., Pitari, G., Reddy, S., Seland, O., Stier, P., Takemura, T., and Tie, X.: An AeroCom initial assessment - optical properties in aerosol component modules of global models, Atmos. Chem. Phys. Discuss., 5, 8285-8330, SRef-ID: 1680-7375/acpd/2005-5-8285, 2005.

Kleinman, L. I., Daum, P.H., Lee, Y-N., Senum, G.I. Springston, S.R., Wang, J., Berkowitz,C. M., Hubbe, J., Zaveri, R.A., Brechtel, F. J., Jayne, J., Onasch, T.B., and Worsnop,D., Aircraft Observations of Aerosol Composition in New England and Mid-Atlantic States During the Summer 2002 NEAQS Field Campaign, J. Geophys. Res. 2006 (submitted)

Lohmann, U., et al., Comparison of the vertical distributions of sulfur species from models participated in the COSAM exercise with observations, Tellus, 53B, 646-672, 2001. 
Lu M-L, J Wang, A Freedman, HH Jonsson, RC Flagan, RA McClatchey, and JH Seinfeld. "Analysis of humidity halos around trade wind cumulus clouds." Journal of the Atmospheric Sciences 60:1041-1059. 2003.

Martins, J.V. et al. Effects of black carbon content, particle size, and mixing on light absorption by aerosol particles from biomass burning in Brazil, J. Geophys. Res. 103, 32041-32050, 1998.

Nakajima, T., A. Higurashi, K. Kawamoto, and J.E. Penner, A possible correlation between satellite-derived cloud and aerosol microphysical parameters. Geophys. Res. Lett., 78, 1171-1174. 2001.Novakov, T., Hegg, D. A. \& Hobbs, P. V. Airborne measurements of carbonaceous aerosols on the East Coast of the United States. J. Geophys. Res. 102, 30023-30030.

Paluch, I.R., The Entrainment Mechanism in Colorado Cumuli, J. Atm. Sciences, 36(12), Dec. 1979, p2467-78.

Perry KD and PV Hobbs. "Influences of isolated cumulus clouds on the humidity of their surroundings." Journal of the Atmospheric Sciences 53(1):159-174. 1996.

Radke LF and PV Hobbs. "Humidity and particle fields around some small cumulus clouds." Journal of the Atmospheric Sciences 48(9):1190-1193. 1991.

Randall, D., M. Khairoutdinov, A. Arakawa, W. Grabowski, 2003: Breaking the cloud parameterization deadlock. Bull. Amer. Meteor. Soc., 84, 1547-1564.

Redemann, J., B. Schmid, J.A. Eilers, R. Kahn, R.C. Levy, P.B. Russell, J.M. Livingston, P.V. Hobbs, W.L. Smith Jr., B.N. Holben, Suborbital measurements of spectral aerosol optical depth and its variability at subsatellite-grid scales in support of CLAMS, 2001, J. Geophys. Res., 62, 9931007, 2005.

Rosenfeld, D. TRMM observed first direct evidence of smoke from forest fires inhibiting rainfall. Geophys. Res. Lett. 26, 3105-3108, 1999.

Taylor GR, S Kriedenweis, and Z Yiping. "The effects of clouds on aerosol and chemical species production and distribution. 1. Cloud model formulation, mixing, and detrainment." Journal of Geophysical Research 102(D20):2385123865. 1997.

Textor, C. , M. Schulz, S. Guibert, S. Kinne, Y. Balkanski, S. Bauer, T. Berntsen, T. Berglen, O. Boucher, M. Chin, F. Dentener, T. Diehl, R. Easter, H. Feichter, D. Fillmore, S. Ghan, P. Ginoux, S. Gong, A. Grini, J. Hendricks, L. Horrowitz, I. Isaksen, T. Iversen, S. Kloster, D. Koch, A. Kirkevåg, J. E. Kristjansson, M. Krol, A. Lauer, J. F. Lamarque, X. Liu, V. Montanaro, G. Myhre, J. Penner, G. Pitari, S. Reddy, $\varnothing$. Seland, P. Stier, T. Takemura, and X. Tie, 2005: Analysis and quantification of the diversities of aerosol life cycles within AeroCom.

Atmos. Chem. \& Phys. Disc., 5, 8331-8420.

Thompson AM, KE Pickering, RR Dickerson, WG Ellis, Jr., DJ Jacob, JR Scala, T Wei-Kuo, DP McNamara, and J Simpson. "Convective transport over the central United States and its role in regional CO and ozone budgets." Journal of Geophysical Research 99(D9):18703-18711. 1994

Twomey, S.A., Piepgrass, M. and Wolfe, T.L. An assessment of the impact of pollution on the global albedo. Tellus 36B, 356-366, 1984. 
Vukovich FM and JKS Ching. "Semi-empirical approach to estimate vertical transport by nonprecipitating convective clouds on a regional scale." Atmospheric Environment 24A(8 pt 2):2153-2168. 1990.

Warren SG, CJ Hahn, J London, RM Chervin, and RL Jenne. Global Distribution of Total Cloud Cover and Cloud Type Amounts Over Land. NCAR/TN-273, National Center for Atmospheric Research, Boulder, CO. 1986.

Wetzel, M.A., and L.L. Stowe, Satellite-observed patterns in stratus microphysics, aerosol optical thickness, and shortwave radiative forcing. J. Geophys. Res., 104, 31,287-31,299, 1999. 